3. Арбузова, Л.Л. Ихтиотоксикология. Уч. пос. / Л.Л. Арбузова-Владивосток: Дальрыбвтуз, 2015. - 92 с. 4. Влияние свинца на изменение показателей углеводного обмена у карпа / П.А. Полистовская, Л.Ю., Карпенко, К.П. Иванова, А.Б. Балыкина// Вопросы нормативно-правового регулирования в ветеринарии. - 2019. №4. - С. 100-102.

5. Динамика некоторых биохимических показателей крови телят, больных субклиническим рахитом / В. А. Трушкин, И. В. Никишина, С. П. Ковалев [и др.] // Вопросы нормативно-правового регулирования в ветеринарии. - 2018. - № 1. - С. 70-72. 6. Лукьяненко В.И. Общая ихтиотоксикология.-
M., 1983,- C. 20-21.

7. Лукьяненко В.И. Физиолого-биохимические аспекты экологического мониторинга: Тез докл. Второй Всес. конф. по рыбохоз. токсикологии, посвящ. 100-летию проблем качества воды в России, г. Санкт-Петербург, ноябрь 1991 г.СПб, 1991- С. 18-20.

8. Уровни радиоактивного загрязнения воды открытых водоёмов и источников питьевого водоснабжения Волго-Вятского региона Российской Федерации / В. Н. Гапонова, Е. И. Трошин, Р. О. Васильев [и др.] // Международный вестник ветеринарии. - 2019. - № 3. - С. 60-66.

\title{
CHANGES IN GLUCOSE CONCENTRATION IN THE BLOOD SERUM OF CARP DUE TO EXPOSURE TO HEAVY METALS
}

L.Yu. Karpenko, P.A. Polistovskaya, K.P. Ivanova

(St. Petersburg state University of veterinary medicine)

Key words: toxicosis, heavy metals, lead, cadmium, zinc, copper, carp, glucose.

The article deals with one of the most urgent problems of aquatic toxicology - the impact of heavy metals on the body of fish. The aim of the study was to analyze glucose indicators in carp after exposure to various concentrations of lead acetate, cadmium, zinc and copper. The experiment included 4 series of experiments, each of which was dedicated to a specific metal (lead, cadmium, zinc, copper). During the research, 1 control group (10 fish) was formed, and in each series of experiments, 3 experimental groups (10 fish) were formed. Experimental groups of fish were contained in a solution of heavy metal acetate with concentrations exceeding the MPC of heavy metals for fishery reservoirs by 10,100 and 1000 times, respectively. The concentration of serum glucose was studied. An increase in glucose concentration due to heavy metal poisoning was found. However, exposure to 10 and $1000 \mathrm{MPC}$ of zinc leads to a decrease in the concentration of glucose in the blood.

\section{REFERENCES}

1. Analysis of the influence of copper on carbohydrate metabolism in carp / P.A. Polistovskaya, A.I. Enukashvili, L.Yu. Karpenko, A.B. Balykina // International Bulletin of Veterinary Medicine. - 2020. No. 2. - S. 162-165.

2. Analysis of the short-term impact of heavy metals on protein metabolism in carp / P.A. Polistovskaya, Karpenko L.Yu., Enukashvili A.I., Ivanova K.P. // International Veterinary Bulletin. - 2020. No. 4. - S. 145-149.

3. Arbuzova L.L. Ichthyotoxicology. Uch. pos. / L.L. Arbuzova - Vladivostok: Dalrybvtuz, 2015. - 92 p.

4. Influence of lead on changes in carbohydrate metabolism indices in carp / P.A. Polistovskaya, L.Yu., Karpenko, K.P. Ivanova, A.B. Balykina // Questions of legal regulation in veterinary medicine. - 2019. No. 4. - S. 100-102.

5. Dynamics of some biochemical parameters of the blood of calves with subclinical rickets / V. A. Trushkin, I. V. Nikishina, S. P. Kovalev [and others] // Questions of legal regulation in veterinary medicine. - 2018. - No. 1. - P. 70-72. 6. Lukyanenko V.I. General ichthyotoxicology. - M., 1983, - S. 20-21.

7. Lukyanenko V.I. Physiological and biochemical aspects of environmental monitoring: Abstracts of the report. Second Vses. conf. for fish farming. toxicology, dedicated. 100th anniversary of water quality problems in Russia, St. Petersburg, November 1991 - SPb, 1991 - pp. 18-20.

8 . Levels of radioactive contamination of water in open water bodies and sources of drinking water supply in the Volga-Vyatka region of the Russian Federation / VN Gaponova, EI Troshin, RO Vasiliev [and others] // International veterinary bulletin. - 2019. - No. 3. - P. 60-66.

\section{АНАТОМО-ТОПОГРАФИЧЕСКИЕ ОСОБЕННОСТИ СТРОЕНИЯ ЛОКТЕВОГО НЕРВА БЕЛОЙ ШВЕЙЦАРСКОЙ ОВЧАРКИ}

\author{
Хватов В.А., Щипакин М.В., Былинская Д.С., Стратонов А.С. \\ (ФГБОУ ВО «Санкт-Петербургский государственный университет ветеринарной медицинь»)
}

Ключевые слова: локтевой нерв, собака, овчарка, анатомия, неврология .

\section{PEФEPAT}

В настоящее время в ветеринарной морфологии уделяется особое внимание изучению периферической нервной системы у животных компаньонов в видовом и породном аспектах. Собаки породы белая швейцарская овчарка особо ценятся в разведении за свои экстерьерные и сторожевые качества, и по сей день являются породой собак, об анатомии которых нет достаточного объема информации. Цель нашего исследования - изучить анатомо-топографические особенности строения локтевого нерва бе- 
лой швейцарской овчарки. Исследования проводились на базе кафедры анатомии животных ФГБОУ ВО «Санкт-Петербургский государственный университет ветеринарной медицины». В качестве датированного материала послужили трупы собак породы белая швейцарская овчарка в возрасте от двух до четырех лет. Всего было исследовано десять трупов, весом 39,5 $\pm 1,0$ кг. В результате проведенного исследования установлено, что у собак породы белая швейцарская овчарка локтевой нерв и его ветви у белой швейцарской овчарки участвует в иннервации зейго- и автоподия, проходя преимущественно по медиальной поверхности предплечья. Также в ходе исследования установлены морфометрические показатели локтевого нерва и его ветвей.

\section{ВВЕДЕНИЕ}

Белая швейцарская овчарка в настоящее время является популярной породой среди животных компаньонов. Данная порода собак славится своими сторожевыми качествами, дружелюбным характером, а также легко поддается дрессировке, в связи, с чем славится у кинологов. Как и все крупные породы собак белая швейцарская овчарка предрасположены к патологиям опорнодвигательного аппарата, и при проведении хирургического вмешательства, а также компьютерной томографии ветеринарным специалистам необходимо учитывать анатомо-топографические особенности строения сосудов и нервов животных $[1,2]$. Проанализировав библиографические данные, мы не обнаружили достаточного объема информации об особенностях строения и морфометрии локтевого нерва у белой швейцарской овчарки, что и послужило целью нашего исследования.

\section{МАТЕРИАЛЫ И МЕТОДЫ}

Исследования проводились на базе кафедры анатомии животных ФГБОУ ВО «СанктПетербургский государственный университет ветеринарной медицины». В качестве датированного материала послужили трупы собак породы белая швейцарская овчарка в возрасте от двух до четырех лет без патологии опорно-двигательного аппарата и нервной системы. Всего было исследовано десять

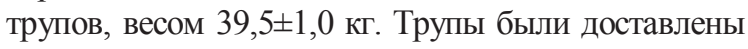
из частных клиник города Санкт-Петербург после вынужденной эвтаназии. В качестве методов исследования были использованы тонкое анатомическое препарирования и фотографирование [5,7]. Для измерения диаметра, ширины и толщины нервных стволов грудной конечности использовали электронный штангенциркуль «Таmo professional» с ценой деления 0,05 мм, производства США $[3,6]$.

Все анатомические и гистологические термины соответствуют «Международной ветеринарной анатомической номенклатуре», пятая редакция, перевод и русская терминология профессора Зеленевского Н. В. [4].

\section{РЕЗУЛЬТАТЫ И ОБСУЖДЕНИЕ}

В результате исследования было установлено, что локтевой нерв у собаки породой белая швейцарская овчарка состоит из волокон восьмого шейного и первого грудного спинномозговых нервов и содержит у собак в большинстве случаев тонкие волокна из второго грудного спинномозгового нерва. Начальный ствол локтевого не- рва объединен со срединным нервом общим эпинервием. Объединённый ствол локтевого и срединного нерва располагается на уровне от плечевого сплетения до большой круглой шероховатости плечевой кости. Указанный ствол на поперечном сечении имеет уплощённую форму. Ширина ствола локтевого и срединного нерва у белой швейцарской овчарки на уровне плечевого сустава в среднем составляет от 4,98 $\pm 0,05$ мм до 5,53 $\pm 0,05$ мм, а толщина 2,03 $\pm 0,02$ мм, до 2,23 $\pm 0,02$ мм.

Локтевой нерв у собаки породой белая швейцарская овчарка, отделившись от срединного, спускается дистально по медиальной поверхности медиальной головки трёхглавой мышщы плеча к локтевому суставу. Диаметр локтевого нерва у изучаемых животных на уровне средней трети плечевой кости в среднем равняется от $1,98 \pm 0,02 \mathrm{MM}$, до $2,20 \pm 0,02$ мм.

Установлено, что в области дистального эпифиза плеча, локтевой нерв у белой швейцарской овчарки проходит вместе с коллатеральной локтевой веной и артерией, в специальном желобе между локтевым отростком локтевой кости и медиальным надмыщелком плечевой кости. Необходимо отметить, что эпинервий локтевого нерва у изучаемой породы собак в этой области значительно утолщается. Диаметр локтевого нерва в области локтевого сустава у данных животных в среднем составляет от 2,19 $\pm 0,02$ до 2,72 $\pm 0,02$ мм.

Несколько дистальнее локтевого сустава, локтевой нерв у белой швейцарской овчарки отдает на каудальную поверхность предплечья каудальный кожный нерв предплечья. Он иннервирует кожу, капсулу локтевого сустава, мышцы сгибатели запястного сустава и суставов пальцев. Отдав ветви в локтевую и плечевую головки глубокого сгибателя суставов пальцев, в локтевой сгибатель запястного сустава, поверхностный сгибатель суставов пальцев, локтевой нерв идет в направлении запястья между локтевыми разгибателем и локтевым сгибателем запястного сустава.

Над запястьем локтевой нерв у собаки белая швейцарская овчарка делится на пальмарную, толстую, и дорсальную, тонкую, ветви. Дорсальная ветвь иннервирует кожу пальмарной и дорсолатеральной поверхности пясти и запястья. А конечная его ветвь переходит на дорсолатеральную поверхность пятого пальца, как дорсальный латеральный пятый пальцевый нерв. Пальмарная ветвь проходит под поперечной связкой запястья и делится на две ветви: поверхностную и глубокую.

Поверхностная ветвь отдает стволик к подош- 
венному мякишу и четвертому поверхностному пальмарному пястному. После этого поверхностная ветвь продолжается на пальмарную поверхность пятого пальца в виде латерального пальмарного нерва пятого пальца. От четвёртого поверхностного пальмарного пальцевого нерва происходят пальмарные пальцевые нервы: медиальный пятого пальца и латеральный четвёртого пальца. После этого поверхностная ветвь анастомозирует со срединным нервом.

Глубокая ветвь проходит под глубоким пальцевым сгибателем вместе с пальмарными пястными артериями, отдаёт веточки в пальмарные мышцы на пясти и делится на второй, третий и четвертый глубокие пальмарные пястные нервы. Последние соединяются со вторым, третьим и четвёртым общими пальцевыми нервами.

\section{ЗАКЛЮЧЕНИЕ}

Таким образом, подводя итоги исследования, можно сделать вывод, что локтевой нерв и его ветви у белой швейцарской овчарки участвует в иннервации зейго- и автоподия, проходя преимущественно по медиальной поверхности предплечья. В связи с этим можно заключить, что при хирургических вмешательствах на локтевой кости у собаки породы белая швейцарская овчарка осуществлять операционный доступ не является рациональным. Полученные в ходе исследования данные расширяют теоретические данные о видовой и породной анатомии домашних плотоядных, а также могут быть использованы ветеринарными специалистами в лечении патологий грудной конечности.

\section{ЛИТЕРАТУРА}

1. Былинская, Д. С. Морфология костей тазовой конечности рыси евразийской / Д. С. Былинская // Актуальные вопросы ветеринарной биологии. 2014. №1 (21). С. 3-9.

2. Былинская, Д. С. Область стопы крупного рогатого скота: кости и сухожилия / Д. С. Былинская, М. В. Щипакин, Н. В. Зеленевский, А. В. Прусаков, Д. В. Васильев // Иппология и ветеринария. 2018. - № 2 (28). - С. 19-24.

3. Зеленевский, Н.В. Скелет туловища рыси евразийской / Н. В. Зеленевский, М. В. Щипакин, К. Н. Зеленевский, А. В. Прусаков, С. В. Вирунен, Д. С. Былинская, В. В. Шедько, Д. В. Васильев, Е. О. Чуркина // Иппология и ветеринария. 2015. - №3 (17). - С. 75-82.

4. Зеленевский, Н.В. Международная ветеринарная анатомическая номенклатура. Пятая редакция / Н. В. Зеленевский // Санкт-Петербург: Лань, 2013 - С. 400.

5. Мамедкулиев, А. К. Анатомическая характеристика мышц области пальцев у овец породы дорпер / А. К. Мамедкулиев, М. В. Щипакин // В сборнике: Актуальные проблемы ветеринарной медицины. Сборник научных трудов № 150. Санкт-Петербург, 2019. - С. 25-26.

6. Стратонов, А. С. Васкуляризация области голени и стопы у свиней пород ландрас и йоркшир в сравнительном аспекте / А. С. Стратонов, М. В. Щипакин // Международный вестник ветеринарии. 2019. - № 2. - С. 111-115.

7. Хватов, В. А. Особенности анатомии мышщ коленного сустава козы англо-нубийской породы / Хватов В. А., Васильев Д. В., Былинская Д. С., Стратонов А. C. // Материалы национальной научной конференции профессорско-преподавательского состава, научных сотрудников и аспирантов. - СПбГУВМ. 2021. - C. 108-110.

\title{
ANATOMICAL AND TOPOGRAPHIC FEATURES OF THE STRUCTURE OF THE ULNAR NERVE OF THE WHITE SWISS SHEPHERD
}

\author{
V.A. Khvatov, M.V. Shchipakin, D.S. Bylinskaya, A.S. Stratonov \\ (Saint Petersburg state University of veterinary medicine)
}

Key words: ulnar nerve, dog, shepherd dog, anatomy, neurology.

Currently, in veterinary morphology, special attention is paid to the study of the peripheral nervous system in companion animals in species and breed aspects. Dogs of the White Swiss Shepherd breed are especially valued in breeding for their conformation and watchdog qualities, and to this day they are a breed of dogs about whose anatomy there is not enough information. The purpose of our study is to study the anatomical and topographic features of the structure of the ulnar nerve in the White Swiss Shepherd Dog. The studies were carried out on the basis of the Department of Animal Anatomy of the St. Petersburg State University of Veterinary Medicine. The corpses of dogs of the White Swiss Shepherd breed aged from two to four years served as dated material. In total, ten corpses were examined, weighing $39.5 \pm 1.0 \mathrm{~kg}$. As a result of the study, it was found that in White Swiss Shepherd dogs, the ulnar nerve and its branches in the White Swiss Shepherd Dog participate in the innervation of the zeigo and autopodia, passing mainly along the medial surface of the forearm. Also, during the study, the morphometric indicators of the ulnar nerve and its branches were established.

\section{REFERENCES}

1. Bylinskaya, DS Morphology of the pelvic limb bones of the Eurasian lynx / DS Bylinskaya // Actual problems of veterinary biology. 2014. No. 1 (21). S. 3-9.

2. Bylinskaya, D. S. Foot area of cattle: bones and tendons / D. S. Bylinskaya, M. V. Shchipakin, N. V. Zelenevsky, A. V. Prusakov, D. V. Vasiliev // Ippologiya and veterinary medicine. 2018. - No. 2 (28). - S. 19-24.
3. Zelenevsky, N.V. The skeleton of the body of the Eurasian lynx / N. V. Zelenevsky, M. V. Shchipakin, K. N. Zelenevsky, A. V. Prusakov, S. V. Virunen, D. S. Bylinskaya, V. V. Shedko, D. V Vasiliev, EO Churkina // Hippology and Veterinary Medicine. 2015. - No. 3 (17). - S. 75-82.

4. Zelenevsky, N.V. International Veterinary Anatomical Nomenclature. Fifth edition / N.V. Zelenevsky // St. Petersburg: Lan, 2013 - P. 400. 
5. Mamedkuliev, AK Anatomical characteristics of the muscles of the finger area in Dorper sheep / AK Mamedkuliev, MV Shchipakin // In the collection: Actual problems of veterinary medicine. Collection of scientific papers No. 150. St. Petersburg, 2019. - P. 25-26.

6. Stratonov, AS Vascularization of the leg and foot in

Landrace and Yorkshire pigs in a comparative aspect / AS
Stratonov, MV Shchipakin // International Veterinary Bulletin. 2019. - No. 2. - S. 111-115.

7. Khvatov, V. A. Features of the anatomy of the knee joint muscles of an Anglo-Nubian goat / Khvatov V. A., Vasiliev D. V., Bylinskaya D. S., Stratonov A. S. // Proceedings of the national scientific conference of professors. teaching staff, researchers and graduate students. - SPbGUVM. 2021 .- S. 108-110.

\title{
DOI: 10.52419/issn2072-6023.2021.4.164 \\ УДК: 611.136.46:636.8 \\ ОСОБЕННОСТИ ХОДА И ВЕТВЛЕНИЯ КРАНИАЛЬНОЙ БРЫЖЕЕЧНОЙ АРТЕРИИ КОШКИ ДОМАШНЕЙ
}

\author{
Прусаков А.В., Яшин А.В. \\ (ФГБОУ ВО «Санкт-Петербургский государственный университет ветеринарной медицины»)
}

Ключевые слова: краниальная брыжеечная артерия, кишечник, кровоснабжение, ангиология, кровеносная система.

\section{PEФEPAT}

На практике ветеринарные врачи часто сталкиваются с кишечной непроходимостью у мелких домашних животных, обусловленной заглатыванием инородных предметов. Как правило, она сопровождается ущемлением обтурирующего тела, что приводит к нарушению трофики участка кишечника и к его последующему некрозу. Оценка возможных последствий данного патологического процесса, а также проведение грамотного хирургического вмешательства по его устранению крайне затруднительны без четких знаний о кровоснабжении кишечника. Цель проводимого исследования - установить особенности хода и ветвления краниальной брыжеечной артерии у кошки домашней. Материалом для его проведения послужили трупы десяти кошек в возрасте от восьми до двенадцати лет, исключая кошек породы мейн-кун. При проведении исследования использовали метод вазорентгенографии. Инъекцию сосудистого русла проводили через брюшную аорту по общепринятой методике. Инъекционную массу изготавливали по прописи: 1 часть сурика свинцового, 8 частей скипидара живичного, 2 части глицерина. После коагуляции инъекционной массы путем проведения тонкого анатомического препарирования из трупа извлекали кишечник вместе с поддерживающей его брыжейкой. Рентгеновскую съемку полученных препаратов осуществляли при следующих технических условиях: сила тока - 50 мА; напряжение на трубке - 35 кВ; фокусное расстояние до 50-60 см; экспозиция - до 1,5-3,0 секунд. Цифровую обработку полученных снимков с целью определения морфометрических параметров осуществляли при помощи программного обеспечения RadiAnt DICOM Viewer. Установлено, что краниальная брыжеечная артерия у кошки домашней, принимает участие в кровоснабжении поджелудочной железы и большей части кишечника, исключая начальный участок двенадцатиперстной кишки, дистальную часть ободочной кишки и прямую кишку. Отходящие от нее ветви богато анастомозируют друг с другом, образуя множество путей коллатерального кровотока.

\section{ВВЕДЕНИЕ}

Изучением сердечнососудистой системы животных занималось большое число исследователей, $[1,2]$. Однако, некоторые вопросы, касающиеся артериального кровоснабжения органов пищеварительной системы, остаются открытыми. На практике ветеринарные врачи достаточно часто сталкиваются с кишечной непроходимостью у мелких домашних животных, обусловленной заглатыванием инородных предметов. Как правило кишечная непроходимость сопровождается ущемлением обтурирующего тела, что приводит к нарушению трофики участка кишечника и как следствие этого к его последующему некрозу $[3,4]$. Оценка возможных последствий данного патологического процесса, а также проведение грамотного хирургического вмешательства по его устранению крайне затруднительны без четких знаний о кровоснабжении кишечника.
В доступных источниках литературы мы встретили усредненные сведенья по интересующей нас проблеме. Учитывая вышесказанное, мы поставили цель - установить особенности хода и ветвления краниальной брыжеечной артерии у кошки домашней.

\section{МАТЕРИАЛ И МЕТОДЫ}

Материалом для проведения исследования послужили трупы десяти кошек в возрасте от восьми до двенадцати лет, исключая кошек породы мейн-кун. Все изученные животные не страдали при жизни заболеваниями органов пищеварения. С целью установления особенностей хода и ветвления краниальной брыжеечной артерии использовали метод вазорентгенографии. Инъекцию сосудистого русла проводили через брюшную аорту по общепринятой методике. Инъекционную массу изготавливали по прописи: 1 часть сурика свинцового, 8 частей скипидара живично- 